\title{
Law, economics and evolutionary theory: state of the art and interdisciplinary perspectives
}

\section{Peer Zumbansen and Gralf-Peter Calliess}

The power of law to survive through centuries is equally apparent. As a consequence a great deal, if not most, of law operates in a territory for which it was not originally designed, or in a society which is radically different from that which created the law. ${ }^{1}$

\section{BEFORE THE EVOLUTIONARY CHALLENGE: ECONOMICS AND LAW DISCOVER INSTITUTIONS AND 'SOCIAL NORMS'}

In 1859 Charles Darwin published his most acclaimed work, On the Origin of Species, and after that nothing was the same in the history of human knowledge. ${ }^{2}$ Darwin's work did not only radically change our perception of the origin and development of nature. His ideas on the mechanisms of evolution were soon transferred to the social sciences, though often in misconceived forms such as 'social Darwinism'3 or caught up in highly charged, polemical debates surrounding school curricula and the collision of religion and evolution. ${ }^{4}$ As Kurt Dopfer recently noted, '[t]he publication of On the Origin of Species by Charles Darwin in 1859 set off a paradigmatic earthquake in the sciences, and to some degree in society at large.' ${ }^{5}$ Since then, evolutionary concepts have been successfully applied, refined and drawn upon to explain long-term developments and change in human relations, societies, culture, and civilization. In jurisprudence, authors such as Henry Sumner Maine ${ }^{6}$ and Oliver Wendell Holmes ${ }^{7}$ have relied on evolutionary ideas for explaining the structures of change in the common law. Despite differences in opinion

\footnotetext{
1 Watson (1982).

2 See Darwin (1859); see further the general overview as to both the roots of and the debate Darwin's ideas created in Bowler (2003).

3 See Johnson (2008); Haferkamp and Smelser (1992), 4-6; for a particular (post WWI) observation on German scientists' embrace of Darwinism, see Keller (1918); see the response of Keller's discussion of social and legal evolution by Brown (1919), 394-400, in particular 397, 398: 'I think the term "legal evolution" a useful and suggestive way of expressing some of the most fundamental characteristics of the long process involved in the history of law.'

4 See, e.g., Frazzetto (2004), 662-665; see also: The Social and Legal Dimensions of the Evolution Debate in the United States, Pew Forum on Religion and Public Life, 4 February 2009, available at: http://pewforum.org/docs/?DocID=396.

5 Dopfer (2005), 3-55, 12.

6 Maine (1861), chapter 2.

7 Holmes (1881), chapters 1 and 2; Holmes (1899), 443-63.
} 
regarding the analogies between biological and legal evolution, legal scholars writing after Holmes generally acknowledged a degree of purpose in legal interpretation and statutory legislation:

A novel statute or precedent suggests [. . .] variation (purposeful, perhaps, but still variation) in a general flow of things in which there is a continuing response to the call of circumstance - adjustment to environment. The nature of the process is apt to be observed by that lack of perspective which prevents us from seeing the old and the new in their true relation. The legislator is not, as he may imagine himself, a Columbus. Not infrequently, he is merely making explicit what was really implicit in pre-existing law. ${ }^{8}$

Besides this distinct disrespect of the Legal Realists for the contention that judges were merely engaged in 'finding' the law, legal scholars quickly began to ascertain the relevance not only of comparative ${ }^{9}$ but also of historical, detailed studies of different legal cultures, if one wanted to make any more generalizable assertions regarding legal change. ${ }^{10}$

Meanwhile, in economic theory, Schumpeter's ${ }^{11}$ emphasis on economic growth as the key to economic analysis helped prepare the ground for evolutionary theory, himself harkening back onto Smith's inquiry into circumstances contributing to the particular dynamics of economic change in his time. ${ }^{12}$ Subsequently, in particular Hayek's 1945 knowledge-based account of market processes ${ }^{13}$ and Alchian's 1950 essay on 'Uncertainty, Evolution, and Economic Theory'14 were among the first to pave the way for a promising promotion of evolutionary concepts in economics, ${ }^{15}$ with important parallel developments in the natural sciences. ${ }^{16}$ As we will discuss below, evolutionary thinking has continued to play a particularly important role in the development of more recent economic theorizing about economic growth and social change, in particular in its challenging the neo-classical economists, again, with Schumpeter sounding the bells of attack early on. ${ }^{17}$ It was above all the focus on the dynamics of economic change in contrast to the neoclassicals' focus on mechanics and to a model analysis of economic equilibria that would eventually open doors to the wealth of institutional and interdisciplinary economic thinking that characterizes the work by scholars such as Douglass C. North, Sidney G. Winter and Richard R. Nelson, Oliver E. Williamson and Elinor Ostrom. This economic analysis is importantly complemented and embedded in the

8 Brown (1919) 394-400, 398, 399.

9 See, for example, Dawson (1968).

10 Watson (1982) 1121-57, 1122, 1124-25: 'To understand the nature of legal change and the relationship between legal rules and society, I believe it is necessary to look at a number of legal systems and at the changes in them over a long period of time.' The article is of particular interest for Watson's response to critics from within the 'law \& society' movement contesting his claim of a 'divergence of law and society'.

11 Schumpeter (1942 [2008]).

12 Nelson (2007), 27-41.

13 Hayek (1945), 519-530; Hayek (2002), 9-23; see also Hayek (1949).

14 Alchian (1950), 211-21.

15 For an account of the parallel emergence of evolutionary thinking in social and natural sciences, see Hull (1988). See also Hull (1995), 67-104, and Haken (2005), 70-85.

${ }_{16}$ See previous note. Compare also Prigogine's observation that ' $[\mathrm{L}] \mathrm{aws}$ of nature no longer express certitudes, but "possibilities", cited in Dopfer (2005), 3-55, 11.

17 Schumpeter (1934 [1983]), (1942 [2008]). 
historical-economic work by scholars such as Joel Mokyr and Paul David ${ }^{18}$ and the sociological work by scholars such as Nico Stehr and Volker Meja. ${ }^{19}$ The 2009 award of the Nobel Prize in Economics to Williamson and Ostrom constitutes an important milestone in the evolution of economic and institutional thought and invites us to cast a light back onto this theoretical trajectory over the preceding decades, opening up an ample view of the manifold overlappings and reciprocal enrichments that have been occurring between economic and legal theorizing. Such attempts at mutual understanding and enrichment are certain to encounter numerous roadblocks and impasses, not least due to the coevolutionary nature of the respective fields and their rationalities. ${ }^{20}$ While the breathtaking ascendance of 'law and economics' ${ }^{21}$ has irreversibly transformed both practice and theory of law, the economist's depiction of this alleged cross-disciplinary dialogue is as legendary ${ }^{22}$ as the potential interdisciplinary dialogue between law and economics has often been limited.

The project pursued in the present volume hopes to go beyond the 'law and economics' perspective that has been so immensely influential in legal practice and academia by focusing on the dimension of evolution within each of the two disciplines in order to carve out, from that perspective, the possible future possibilities and directions of crossdisciplinary pollination between legal and economic thinking. With both disciplines inherently aspiring to conceptualize models, principles and systems of social order, the discovery of a dynamic dimension in the development of the respective apparatus could not come as a surprise: evidently, in both disciplines, law and economics, different ideas of evolution have long inspired a host of varying usages and assessments. ${ }^{23}$

Our suggested task of identifying instantiations of a meaningful reciprocal engagement between legal and economic thought is likely to bring to the fore particular moments of debate or outstanding publications that had a decisive impact on the development of this disciplinary co-existence. Clearly, Coase's 1960 article on 'The Problem of Social Cost', said to have 'had more policy influence than any other economic text', ${ }^{24}$ marks without doubt one such historical moment. The research and teaching agenda it projected for lawyers in the decades to come, were immense, despite Coase's own perhaps tongue-incheek assertion that his interest in fact had never been to give rise to any such thing as 'law and economics'. ${ }^{25}$ Aptly identified by Coase then and later, was the complexity of adequately bridging the two disciplines in order to make meaningful assertions across the fence. And yet, today, there can be no doubt that in spite of such challenges, lawyers have

\footnotetext{
18 See Mokyr (2002), Ch. 7, and Mokyr (2005a); Mokyr (2005b), 195-218; Mokyr, in this volume. David (2008), 151-194; David, in this volume.

19 Stehr (2002); Stehr (2005), 299-322.

20 Dopfer (2005), 3-55, 18: 'A young discipline, such as evolutionary economics, suffers from a language deficit.' Compare with Amstutz, in this volume and with Teubner (2002), 161-82.

${ }_{21}$ Branson (1989), 745, likened its proliferation in academic corporate law to a 'prairie fire'. See also, Cheffins (2004).

22 See only the debate between Coase and Simpson: Simpson (1996a), 53-97; Simpson (1996b), 99-101 and Coase (1996), 103-119. See also the recent revisiting of this dispute by Hovenkamp (2009), 633-49.

23 For an excellent assessment, see Elliott (1985), 38-94.

24 Hovenkamp (2009), at 649.

25 Coase (1996), 103-119, 104-105.
} 
anything but grown tired to apply economic thinking to the development of legal frameworks, across a wide range of legal fields. Meanwhile, economists have been persistent in assessing the role and increasingly the 'nature' of legal regulation in relation to alternative forms of social ordering, something that has been both informing and shaping the evolution of theoretical work done on property rights ${ }^{26}$ on the basis of which emerged comprehensive concepts of economic governance, ${ }^{27}$ the economics of institutions, ${ }^{28}$ institutional diversity, ${ }^{29}$ and social norms. ${ }^{30}$ This work has altogether contributed to the development of fairly robust assessments of the 'environment' of economic development drawing on a host of different disciplinary depictions of formal and informal institutions. ${ }^{31}$ As powerfully illustrated by the recently again increased interest in 'informal rules', or social norms, there appears to be a shared perception among economists and lawyers of how customs, social practices, indigenous norms can fit into the description of legal enforcement mechanisms embedding an otherwise far-reaching system of social self-regulation, precisely because the 'legal' nature of these social norms is in question. Particularly in light of the work done by sociologists and lawyers regarding the changing nature of state regulation in the context of privatization of norm-creation and the delegation of lawmaking authority to private and quasi-public bodies, ${ }^{32}$ economic theorizing has become increasingly sensitive to the underlying assumptions relating to the desired stability of property rights enforcement, ${ }^{33}$ with the more long-term consequences of this development and the more recent interest in the cognitive basis for individual choice-making ${ }^{34}$ still to be assessed. What seems to be clear, however, is that both economists and legal scholars are hard at work at further scrutinizing the dynamics of the evolution of both formal and informal rules, the former being interested to a large degree in the challenges of informal rules to the devising of sound economic models for emerging or transforming economies, ${ }^{35}$ while the latter are engaged in a critique of the political nature of social norms. ${ }^{36}$

26 Demsetz (1967), 347-59; North (1981), 17-19.

27 Williamson (2000), 595-613; Williamson (2005), 1-18.

${ }^{28}$ Eggertsson (1990); Eggertsson (1996), 6-24, 25: ' . . . at the frontier of research there is also a need and scope for experimental work with an alternative paradigm.'

29 Ostrom (2007), 239-64.

30 Drobak (2006).

31 Eggertsson (1996), 6-24, 11: 'As the institutional framework consists of formal and informal rules and their enforcement, research at this level intrudes into the domain of political science, sociology, and anthropology, along with law and history.'

32 A good overview is provided by Lobel (2004), 342-469. See also the analysis and critique by Aman Jr. (2007), 802.

33 Ostrom (2007), 239-64; see already Ostrom (2005), 21-22, drawing on the legal pluralist critique on rigid rule categorizations along the lines of 'public' or 'private'.

34 Eggertsson (1996), 6-24, 21; see also Aguilera et al. (2004), 836-863.

35 See e.g. Williamson (1996); and from the point of view of law, see Posner (1998), 1-11.

36 Posner (2000); Hadfield and Talley (2006), 414 41; see the discussion in Calliess and Zumbansen (2010), ch. 2, ch. 5. 


\section{MEANWHILE: ADVANCES IN SOCIOLOGICAL THEORY, ECONOMICS AND LAW}

In many ways, these developments can be said to have their origin in theoretical advances made in sociology, economics and legal theory. As regards the first, in 1983, the German sociologist Niklas Luhmann published what would soon be regarded as a seminal work: Social Systems. In this book, Luhmann reconceptualized Talcott Parsons' theory of social systems on the basis of the biological concept of autopoiesis. ${ }^{37}$ Luhmann thus aimed at developing an all-encompassing theory of society as a self-referential system of communication, explicitly drawing upon evolutionary approaches. ${ }^{38}$ Luhmann's concept of evolution, which constituted a crucial element for his general theory of society, played a decisive role for law: by explaining how evolution occurred through an unending process of variation, selection and retention, Luhmann was able to provide an intricably persuasive model for the explanation of legal change - a model which was on the one hand extremely sensitive to the 'embeddedness' of law in social structures - much like the Realists had indeed seen it - but at the same time, emphasizing law's particular mode of change, adaptation and evolution. ${ }^{39}$ With view to the fate of evolutionary theory in law, it is important to note, that legal theorists close to systems theory - such as Gunther Teubner $^{40}$ and Karl-Heinz Ladeur ${ }^{41}$ - have always insisted on a particular, critical distance to social theories of law's embeddedness on the one hand and to theories of the 'unity of law'42 on the other, while certainly engaging with the same conceptual challenges - concerning the relationship between law and society - that these theories were facing. Over time, these explorations have contributed to a considerably rich landscape of conceptual and theoretical assessments of law's evolutionary trends and prospects - studies that eventually received important impulses from both comparative legal scholarship ${ }^{43}$ as well as from a fast emerging scholarship focusing on the conundrical yet intriguing coupling of 'globalization and the law' ${ }^{44}$ The continuing, indeed highly productive tension between normative and systems theoretical accounts of the continuing transformation of state governance within and beyond the confines of the nation state has been informing and shaping an immensely rich debate. ${ }^{45}$

\footnotetext{
37 Luhmann (1996).

38 See also Luhmann (1975), 150-169; Luhmann (1978), 413-440; Luhmann (1989), 176-220.

39 For a concise reconstruction of law's mode of change, see only Teubner (1984), 291-301; but see also the recent, highly interesting development of this theory in Teubner (2009), 1-23.

40 Teubner (1983), 239-85.

41 See the April 2009 German Law Journal Symposium in celebration of Professor Ladeur's work 'The Law of the Network Society' (eds.,L Viellechner et al., http://www.germanlawjournal. com/pdf/Vol10No04/pdf_table_of_contents_Vol_10_No_04.pdf).

42 See, for example, the work by Baldus (1995), and by Felix (1998); for an earlier, decidedly political rejection of a concept of 'unity of law', see Neumann (1964), 22-68, and the excellent study on Carl Schmitt by Maus (1980).

43 See Frankenberg (1985), 411-55; Buxbaum (1996), 201-230; Sacco (2002), 727-36; Reimann (2002), 671-700; Glenn (2005), 863-98; Riles (2005), 973.

44 Teubner (1992), 1443-62; Teubner (1997a), 763-87; Zumbansen (2002), 400-432; Calliess (2001); Berman (2005), 485-556; Scott (2005), 757-73.

45 See, for example, the contributions to Brunkhorst (2009), Schulte and Stichweh (2008) and Zumbansen and Skordas (2009). See already the contributions to Niesen and Herborth (2007).
} 
Around the same time that Luhmann published 'Social Systems', a small revolution occurred in economics that elevated evolutionary theory onto a stage for everyone to see and consolidated its place in the discipline: In 1982, the economists Richard Nelson and Sydney Winter laid out a systematic account of evolutionary elements in the theory of business and economics, ${ }^{46}$ by publishing a book that has been depicted as an ice-breaker that arguably gave the early process its critical momentum'. ${ }^{47}$ At the outset of their programme was the observation that the dramatic dimensions of technological change posed particular challenges to economic theories of growth. From this premise, Nelson and Winter revisited Schumpeter's contribution in search of inspiration and encouragement ${ }^{48}$ to think beyond neo-classical frameworks that they found to be at odds with a highly differentiated landscape of economic innovation and production. ${ }^{49}$ Building on and expanding further a 'behavioral' approach to firms, ${ }^{50}$ Nelson and Winter posited against the neo-classical assumption of firms' maximization orientation - that 'a firm at any time operates largely according to a set of decision rules that link a domain of environmental stimuli to a range of responses on the part of firms. While neoclassical theory would attempt to deduce these decision rules from maximization on the part of the firm, the behavioral theory simply takes them as given and observable. ${ }^{51}$ At the heart of their concept of the firm as operating within a particular environment was the idea that it would be impossible to describe the dynamics of change of inter-organizational decisions without taking into account the manifold input and output relations between the firm and its - constantly changing ${ }^{52}$ - environment. This contention still lies at the base of Nelson's and Winter's theory today: 'At the broadest level, and possibly the deepest, the difference between evolutionary economic theory that is taking shape, and the neoclassical theory that has dominated microeconomic theorizing over the last thirty years, is that evolutionary theory sees the economy as always in the process of change, with economic activity almost always proceeding in a context that is not completely

46 Nelson and Winter (1982); see already their essays leading up to the book: Nelson and Winter (1973), 440-449; Nelson and Winter (1974), 886-905; for a discussion of Nelson's and Winter's proximity to Schumpeter and an ultimately skeptical assessment of Nelson's \& Winter's contribution, see Ruttan (1997), 1520-1529, at 1524: 'dead end'.

47 Dopfer (2005), 3-55, 3.

48 Nelson (2006), at 4 'strongly inspired by Schumpeter'.

49 Nelson and Winter (1974), 886-905, 890: 'It seems obvious that research on economic growth within the neoclassical theory is creating new intellectual problems more rapidly than it is solving them. One can continue to search for solutions to these problems guided by the assumptions of neoclassical theory. Or, one can try a new tack.'

50 See already Alchian (1950), 211-21, 218: ' . . the consequence of this is that modes of behavior replace optimum equilibrium conditions as guiding rules of action.'

51 Nelson and Winter (1974), at 891.

52 Alchian (1950), 211-21, 219: 'Comparability of resulting situations is destroyed by the changing environment. As a consequence, the measure of goodness of actions in anything except a tolerable-intolerable sense is lost, and the possibility of an individual's converging to the optimum activity via a trial-and-error process disappears. Trial and error becomes life or death. It cannot serve as a basis of the individual's method of convergence to a "maximum" or optimum position. Success is discovered by the economic system through a blanketing shotgun process, not by the individual through a converging search.' 
familiar to the actors, or perfectly understood by them. ${ }^{53}$ In the following, this approach has inspired a true plethora of innovative studies in management ${ }^{54}$ and organizational studies, ${ }^{55}$ industrial organization, ${ }^{56}$ the theory of the firm,,${ }^{57}$ in political economy ${ }^{58}$ as well as in legal theory. ${ }^{59}$ Meanwhile, the originators of this line of thinking have themselves embarked on a very fruitful revisiting and further development of some of their initial starting points, ${ }^{60}$ eventually opening up perspectives for a better understanding of evolutionary processes as 'learning processes'. ${ }^{61}$

\section{THE ROLE OF INSTITUTIONS IN ECONOMIC THOUGHT}

Among these, sociology as well as business and economics seem to have taken the lead in further developing evolutionary theories of institutional change, ${ }^{62}$ spurred by the emergence of New Institutional Economics centring around Douglass North $^{63}$ and Oliver Williamson ${ }^{64}$ - with 'new' evolutionary economics continuing to push for further sophistication of the theoretical apparatus. ${ }^{65}$ The importance of this research lies in its untiring - if varied - engagement with the tension between market and non-market regulation, a tension which powerfully unfolds from within the definition of 'institutions'. In Professor North's words, 'Institutions are the humanly devised constraints that structure political, economic and social interaction. They consist of both informal constraints (sanctions, taboos, customs, traditions, and codes of conduct), and formal rules (laws, property rights). ${ }^{66}$ In his important study of 1990, he observed: 'As defined here, they [institutions] therefore are the framework within human interaction takes place. ${ }^{97}$ It is against this relatively flexible definition that North has been arguing for the central role of institutions for long-term economic performance. North's contribution to an increasingly interdisciplinary dialogue concerning market regulation in historical perspective can hardly be overestimated. As academic interest in the nature, culture and trajectory

\footnotetext{
53 Nelson (2006), 1. See also Nelson (1995), 48-90.

54 Mahoney and Pandian (1992), 363-80.

55 Zollo and Winter (2002), 339-51.

56 Dosi and Malerba (2002), 619-22.

57 See, for example, Whittington et al. (1999), 519-551, and the contributions to Dimaggio (2001).

58 Hall and Soskice (2001).

59 See, e.g., G. Teubner (1999a), 7-25 in Ziman (2002), 161-82

60 See, in this context, Nelson (2007), 27-41,31, highlighting the need to take a more comprehensive look at the institutions shaping technological change, here referring to 'social technologies'.

${ }_{61}$ Nelson (2007), preceding note, at 34.

62 Nelson (1995), 48-90.

63 North (1990); North (1991), 97-112; North (1994), 359-68 (Nobel Prize Lecture); North (2005).

64 Williamson (1985); Williamson (1981), 1537-68.

65 Nelson (2006), 6: 'The new evolutionary growth theory that is emerging sees economic growth as the result of the coevolution of technologies, firm and industry structures, and supporting and governing institutions.'

66 North (1991), 97-112, at 97.

67 North (1990), at 4.
} 
of the market ${ }^{68}$ among legal scholars, economists, economic historians, geographers and political economists again soared in recent years, ${ }^{69}$ Douglass North's insistence on an interdisciplinary, historically grounded analysis of the different institutions that structure market behaviour proved to be a crucial contribution to a more engaged and more challenging exchange between scholars in different disciplines. Building on and eventually substantively expanding his earlier interest in 'institutions' per se, North in his more recent work has adopted a decidedly social-theory perspective, from which he places a central emphasis on the nature and volatility of societal change and on the resulting uncertainty, that characterizes long-term oriented theorizing. Central to this reorientation is the role of intentionality with regard to institutional change. ${ }^{70}$ With this, North connects his important institutionalist framework to the increasingly influential ${ }^{71}$ work in behavioural finance ${ }^{72}$ and behavioural law and economics ${ }^{73}$ and makes thus a powerful argument for the necessity to take the complexity of market structures and behaviors seriously - a lesson which will continue to inspire future interdisciplinary research not only in corporate finance and corporate governance, ${ }^{74}$ but also in economic sociology, geography and regulatory theory. ${ }^{75}$ Next to the field of economic geography that has been gaining new attraction for economists and globally oriented policy makers with regard to regional differences in economic growth and development, ${ }^{76}$ and regulatory theory, which over the past 15 years has become something of an umbrella concept for interdisciplinary governance studies, ${ }^{77}$ it is in economic sociology that we can see a number of important

68 See of course already White (1981), 517-47.

${ }_{69}$ See, e.g., Lie (1997), 341-60; Rosenbaum (2000), 455-82; Fligstein (2001); see also the contributions to Nee and Swedberg (2005a), and Nee and Swedberg (2005b), 789-818. Besides the recent renaissance in economic sociology, the contributions by scholars interested in the 'Varieties of Capitalism' are of particular interest in this regard: see, e.g., the landmark volume by Hall and Soskice (2001), and the preceding work by Soskice (1999), 101-134, and Hollingsworth (1997), $133-47$, as well as Streeck (2001), 1-38.

70 North (2005).

${ }^{71}$ See the hesitant treatment, at the time, by one of the most astute scholars of the Efficient Capital Market Hypothesis (ECMH) himself: Fama (1998), 283-306, 284: 'anomalies'.

72 See the foundational work on the ECMH by Fama (1970), 383-417; Jensen (1970), 95-101; Gilson and Kraakman (1984), 549-644 - see also Gilson and Kraakman (2003), 715, and Stout (2003), 635 .

73 See the contributions to Sunstein (2000); for a very informative discussion and overview, see Klöhn (2006), 80-153.

74 See the brilliant example: Aguilera et al. (2004), 836-63.

75 As a representative example of work grown out of long-term analysis of the shortcomings of the ECMH, see the scholarship by Thaler (1987), 197-201; Thaler (1999), 12-17; see now Thaler and Sunstein (2008).

76 See, e.g., the World Bank (2009); see the contributions to Clark et al. (2003); see also the famous launch by Paul Krugman in 1992 of 'new economic geography' (Krugman (1992)), and Krugman (1998), 7-17; see further relatively recent creation of a new academic journal in this area: Journal of Economic Geography (OUP, since 2001), complementing among others the longstanding Economic Geography (Clark University, since 1925).

77 See, e.g., the overview by Burris et al. (2008), 1-66; see also the meanwhile seminal article in legal scholarship by Lobel (2004), 342-469; for a refreshing perspective with regard to the EU, see Möllers (2006), 313-36; with regard to global financial regulation, see the poignant contribution by Black and Rouch (2008), 218-33. 
strides in recent years, both with regard to its engagement with institutional economics as well as with law. ${ }^{78}$ It is from here that important impulses for a more serious, interdisciplinary study of 'law in context', 'law and society' and 'social norms' in their relation to traditional jurisprudence are likely going to be received still. ${ }^{79}$

Surely, not only at a time such as when The Economist would dedicate an issue to 'Modern Economic Theory. Where it went wrong - and how the crisis is changing it' with a number of outspoken defamations of financial economics' hubris concerning perfect markets $^{80}$ have economists cast models into doubt that had been designed to explain economic growth. As indicated above, after Keynes' 1936 General Theory and its eventual interim relativization (and subsequent revival ${ }^{81}$ ), the theoretical advances by North and other scholars of New Institutional Economics ${ }^{82}$ are among the most sophisticated and most promising economist contributions to an integrated analysis of economic developments. It is in fact on the basis of and in engagement with the wealth and the challenging, analytical potential of the institutionalist framework that other disciplines such as political economy, economic sociology, economic geography and, certainly, law have been developing over the past decades. This context makes for an intriguing moment to engage in an interdisciplinary analysis of the evolutionary trajectories of law and economics. The proffered depictions, explanations and assessments as they are voiced with regard to the 2008 financial and economic crisis, not only by those who had always 'known', 'warned' or were 'ignored', feed into and complement what will continue to unfold as a crucially important theoretical engagement with the models and toolkits economists, lawyers and social theorists have been relying on since the early 1980s. While the need for an interdisciplinary and integrated study of the current crisis thus lies in the evident ambiguity of the very starting points of any assessment, ${ }^{83}$ the promise of an interdisciplinary study of institutions goes further still: precisely because of the distinct premises and normative orientations in legal and economic thinking, there is a great need for continued translation of methodological approaches in both disciplines. ${ }^{84}$ The appearance of one in the

78 See only Nee and Swedberg (2005b), 789-818, 795: 'Slowly [. . .] it has been realized by economic sociologists that law constitutes a central part of the modern economy .... See, in this context, Swedberg (2003), 1-37.

79 See, e.g., the definition of 'institution' provided by Nee and Swedberg, op. cit., 797-8: 'An institution may be conceptualized as a dominant system of interrelated informal and formal elements - customs, shared beliefs, norms, and rules - which actors orient their actions to when they pursue their interests. In this view, institutions are dominant social structures which provide a conduit for social and collective action by facilitating and structuring the interests of actors and enforcing principal agent relationships. It follows from this interest-related definition that institutional change involves not simply remaking the formal rules, but requires the realignment of interests, norms, and power.'

80 The Economist, 18-24 July 2009, 12, 68-72.

81 Skidelsky (2009); Davidson (2009).

82 For an interim excellent introduction and overview see Voigt (2002); meanwhile, see Williamson (2005), 1-18, and Ostrom (2005), and the contributions to Ostrom (2007), 239-64. A very instructive paper is still Williamson (2000), 595-613.

${ }_{83}$ For an intriguing perspective on the correlation of different periodizations, see Mokyr (2005a).

84 Calliess and Renner (2009), 260-80, 262. 
other - economics in law ${ }^{85}$ and law in economics ${ }^{86}-$ has indeed increased rather than limited the need for further dialogue and translation.

As legal scholars and economists continue to demarcate the boundaries of states and markets, we can discern a lot of parallel engagement with evolutionary theory's conceptualizations of institutional lock-in ${ }^{87}$ and path-dependency: ${ }^{88}$ such studies are particularly relevant with regard to lawyers' and economists' ongoing attempts to gain a better understanding of the meaning and lessons from 'market failure', a term that has frequently been referred to not only for an identification of the occasion but also of the scope of state intervention. ${ }^{89}$ Market failure thus presents a formidable example for the illustration of the urgent need of collaborative and interdisciplinary analysis of the institutions involved in successful or failing regulation. For law, a study of market failure goes to the heart of its own understanding, as the definition of a legal concept of market is intimately tied to the foundational understanding of law as such, ${ }^{90}$ because it cannot simply presuppose a market as such. ${ }^{91}$ In turn, for economics, and for New Institutional Economics in particular, the question is whether the theoretical framework has a convincing analytical and conceptual grip on contemporary complex regulatory constellations. As has repeatedly been highlighted by Paul David, the general observation that 'history matters' ${ }^{\prime 92}$ by itself is about as explanatory or illuminating as the claim that market failures challenge the embedding legal enforcement system in a straightforward, causal manner: ${ }^{93}$

From the foregoing it may be seen that a proper understanding of path-dependence, and of the possibilities of externalities leading to market failure, is not without interesting implications for economic policy. But those are not at all the sorts of glib conclusions that some critics have alleged must follow if one believes that history really matters - namely, that government should try to pick winners rather than let markets make mistakes. Quite the contrary ... [...]. One thing that public policy could do is to try to delay the market from committing to the future inextricably, before enough information has been obtained about the likely technical or organizational and legal implications, of an early, precedent-setting decision. ${ }^{94}$

In another paper, Professor David observed that

[I]f there are ways thus to represent the coevolution of microeconomic behavior with regard to technology choices (technical standardization), or conformance with social norms (custom and

\footnotetext{
85 Rubin (1977), 51-63; Priest (1977), 65-82; Eidenmüller (1995); Kennedy (1982), 563.

86 Bernstein (1992), 115-157; Hadfield (2001), 40-45; Greif (2006).

87 Arthur (1989), 116-131.

88 Arthur (1989), preceding note; Arthur (1994); David (1985), 332-7; see also Baumol (1986), 1072-85; Roe (1996), 641-68.

89 Zerbe Jr and McCurdy (2000), 10-14, at 10.

90 Hale (1923), 470-94; Wiethölter (1972), 531-9; Campbell (1997), 307-336; Zumbansen (2007a), 191-233; see also Lindblom (1995), 684-8, 685: 'Market rules do not permit one simply to appropriate what one wants. Appropriating another person's labor we call slavery, and appropriating assets we call theft. Nor do market rules provide any social instrument for collective reassignment of claims.'

91 See only Hale, previous note; see also the instructive discussion and analysis in Johns (2007), $116-38$.

92 David (2000).

93 David (2008), 151-94.

94 David (2000), 14.
} 
convention) and correlated patterns of ideology or beliefs carrying normative force (subjective conformism), the explanatory apparatus available to economists studying long-term trends in technology and social institutions will surely be much more powerful. ${ }^{95}$

As pointed out by Duncan Kennedy, in a comment on Robert Clark, 'costs' are a merely allusive concept, that can hardly carry enough weight on their own to identify or even justify action on the part of a public or private actor. ${ }^{96}$ Tightly connected to such an observation is David's own contention that we must apply a much more differentiated toolkit to explore the interaction between different market actors over time in order to get a better understanding of why things go wrong and how we arrive at such an assessment. What emerges from Professor David's observations is a cautionary approach towards a concept of market failure that is not again re-embedded in a comprehensive historical and systematic institutional study. 'History matters', then, is not a sophisticated enough proposal to engage in a layered, interdisciplinary analysis of how which institutions play a crucial role in the organization of today's market economies. While the concept of path dependency has been developed primarily with confined, nationally grown markets in mind, its relevance for transnational markets and transnational regulatory theory follows from the realization of the stickiness of existing (and newly created) regulatory structures, something which - as before in the case of lex mercatoria ${ }^{97}$ - any globally or transnationally aspiring regulatory concept will necessarily have to take into account. ${ }^{98}$

\section{TOWARDS A RENEWEDINTERDISCIPLINARY PERSPECTIVE}

What follows from the above is that an evolutionary perspective is crucial in the emerging new phase of interdisciplinary inquiry into the relationship between 'public' and 'private' ordering, 'state' vs. 'market' regulation and that there is a continued need to further refine the concept of 'institution'. For such an interdisciplinary dialogue to unfold in an effective way, the continued engagement with each other's methodological starting points and premises is crucial. It is thus necessary to open up respective toolkits and analytical frameworks to comparative and interdisciplinary scrutiny.

It is then against this background, that we can begin to see how reflections, internal to economist and economic-historical theorizing, are in fact mirrored, paralleled and sometimes even anticipated in other disciplines that have been engaging, one way or the other,

\footnotetext{
95 David (2008), 175.

96 Kennedy (1981), 1275-83, at 1281: 'an obstacle because it makes the world as it is look rational and necessary, even just (who can object to "cost reduction"?), as opposed to arbitrary and contingent. This is a misrepresentation that has an effect: it diverts energy from the job of finding the truths we need to know about the world if we are to be effective in transforming it; it diverts energy from the task of figuring out what the world should be like.'

${ }_{97}$ Drahos and Braithwaite (2001), 103-128, 110, 111: 'a spectacular example of transnational private ordering'. With regard to the authors' characterization of the bottom-up nature of lex mercatoria as an example of transnational norm creation, see also J. Koven Levit (2007), 393-420, and L. Catá Backer (2009).

98 P. Zumbansen (2007b), 467-96, 488; Zumbansen (2008), 246-76; Calliess and Zumbansen
} (2010). 
with the concept or the idea of institutions in the recent past. ${ }^{99}$ Within law, and in particular outside of contract law which has attracted a plethora of focused assessments from the part of New Institutional Economics (NIE), ${ }^{100}$ there has certainly been an intensive and fruitful engagement with NIE in corporate law theory. ${ }^{101}$ More recently still, NIE has been subject to lively exchanges within Public International Law. ${ }^{102}$ Another example is the recent revival of lawyers' interest in Hayek's idea of spontaneous evolution. ${ }^{103}$ Partly in answer to such developments, partly in building on earlier starting points in Marx, Durkheim and Weber, the recently newly burgeoning field of economic sociology ${ }^{104}$ has been making extremely fruitful contributions to an altogether inspiring, interdisciplinary discussion about the nature of markets and institutions. ${ }^{105}$ For their part, lawyers have been pressured to respond to this challenge from a particular set of perspectives, partly constituted through the uncertainties connected to increasingly contractualized public services and a fundamental reconsideration of law's role in market regulation, ${ }^{106}$ partly through an intricate mix of privatized ${ }^{107}$ as well as transnational ${ }^{108}$ modes of norm-generation. This development within legal doctrine and legal theory - in the midst of which we find a vividly continuing debate about 'social norms'109 - is of interest

99 A brilliant historical and conceptual analysis is provided by Joel Mokyr, The Institutional Origins of the Industrial Revolution, unpublished Ms., Northwestern University 2007.

100 Here, the field is vast and polarized: see, e.g., Williamson (2000), 595-613, 599; Scott (2004), 369-90; Campbell (2004), 645-78.

101 See the early contributions, building on Coase (1937, 1960), by Alchian and Demsetz (1972), 777-95, Fama and Jensen (1983), 327-49, and Williamson (1981), 1537-68; building on these foundations, e.g., Roe (1996), 641-68; Roe (2002), 233-71; Cheffins (2001), 459-84; Cheffins (2004), 456-506; Bratton and McCahery (2001); Gourevitch (2003), 1829-80; Zumbansen (2006), 534-56.

102 van Aaken (2009), 33-57; Zumbansen (2009), 62-70; Guzman (2008), and the Symposium on Guzman's book in 1 International Theory 283-343 (2009).

103 See Hayek (1960 [2006]), 53: 'For the first time it was shown that an evident order which was not the product of a designing human intelligence need not therefore be ascribed to the design of a higher, supernatural intelligence, but that there was a third possibility - the emergence of order as the result of adaptive evolution'; for the distinction between 'economy' (as 'an organization or an arrangement in which someone consciously uses means in the service of a uniform hierarchy of ends') and 'market' ('spontaneous order'), see Hayek (1968 [2002]), 9-23, at 14; see already F. Hayek (1945), 519-30, reprinted in Hayek (1949 [1996]), 77-91 at 88: 'We make constant use of formulas, symbols, and rules whose meaning we do not understand and through the use of which we avail ourselves of the assistance of knowledge which individually we do not possess. We have developed these practices and institutions by building upon habits and institutions which have proved successful in their own sphere and which have in turn become the foundation of the civilization we have built up.' For a defence against an outsider's critique of the normative implications of spontaneous order, see, e.g., Sugden (1989), 85-97, 97; see also the recent discussion, see Hardos and Rahoc (2008).

104 For an assessment, see Nee and Swedberg (2005b), 789-818.

105 Beckert (2007); Beckert and Streeck (2008), Beckert (2009), 245-69. Nee and Swedberg (2005b), 789-818; see already the landmark work by Swedberg (1998), and the collection of essays in Nee and Swedberg (2005b).

106 Aman Jr (2001), 379-400; Teubner (1999b), 51-82; Zumbansen (2008a), 769-805.

107 Ellickson (1991).

108 Teubner (1997b), 3-28.

109 See Posner (2000); Drobak (ed) (2006); for a critical perspective see the author of 'Order without Law', Ellickson (1998), 537-565; see also the magnificent analysis of the inherent 
beyond the unsurprisingly recurring, traditional lawyers' laments concerning the loss of regulatory capability and sovereignty. ${ }^{110}$ Even before the recent economic crisis began to unfold, it had become clear to regulatory and legal theoreticians that the transformation of Western welfare states in the context of an IT-driven globalization of markets of goods, production, services and migration posed a new set of conceptual challenges that could henceforth only be approached from within an interconnected interdisciplinary agenda. ${ }^{111}$

And yet, despite these manifold intersections, the different strands of evolutionary theory have not been brought together for a comprehensive analysis of the change of legal and economic institutions. The elephant in the room continues to be the tension between economic and legal governance, or more precisely the relation between the social order as conceived either from an economic or from a legal perspective. So far unanswered remains the question regarding the reasons for the existence of a legal order beyond its affirmation as an enforcement framework for market ordering. As shown by Donald Elliott's astute analysis of evolutionary theories in legal and economic scholarship 25 years ago, 'Economic theories of legal evolution also depend on the assumption that a legal system already exists.' ${ }^{112}$ By not, however, being able to answer whether the legal system predates - historically or normatively - the economic system, the economic story of markets and their embeddedness in a legal enforcement mechanism remains on a purely abstract level: it distinguishes between the market and the state by resorting to terms such as market and non-market order mechanisms. This, however, attempts to answer the question as to what constitutes the relation between the two spheres without providing for a definition of or a justification of the distinction in the first place. That the legal system exists to remedy market failures does not explain whether the market failure is in fact something else than a political or regulatory failure. ${ }^{13}$ It is here, where the evolutionary strands in law, economics and sociology have much to contribute.

\section{CONCLUSION: LEGAL AND ECONOMIC GOVERNANCE OF THE TRANSNATIONAL KNOWLEDGE SOCIETY}

It is a certain irony, that not only the politically self-conscious exclamation that 'We are all Realists Now', resounding many years ago, ${ }^{114}$ would eventually be succeeded by the

\footnotetext{
depoliticizing effects of the anti-regulatory efficiency claim advanced by norm proponents, by Charny (1996), 1841-58, one of the many outstanding papers in the excellent Symposium Issue on 'Law, Economics, and Norms', published in 144 University of Pennsylvania Law Review 16432339 (1996); with regard to the 'norms vs. regulation' conflict for example in the current debate over a Common Frame of Reference for European Private Law, see, on the one hand: Smits (2006), 85, and, on the other: Hesselink (2008).

110 Zumbansen (2007c), 181-190.

111 See e.g. Levi-Faur (2004), 12-29, and Sassen (2003), 1-22; Ladeur (2000).

112 Elliott (1985), 38-94, at 71.

113 For an early analysis of this connection, see of course Hale (1923), 470-494; Cohen (1927), $8-30$.

114 Singer (1988), 465-544, at 467.
} 
realization that, in fact, 'We are all Economists Now', ${ }^{115}$ but that we seem to now be experiencing yet another relativization of perspective. A pronouncement of the sort 'We are all Interdisciplinary Governance Scholars Now', would, however, have only a faint ring to it. The underlying conundrum is that of the trajectories of institutional and normative change, which occupy much of economic and legal inquiry, before and in light of the global financial and economic crisis of 2008-2009. Meanwhile, the intellectual competition over the primacy of economic or legal reasoning in the imagination of ('sustainable', 'good', 'just') governance occurs in the shadow of a dramatic transformation of the spaces for economic and legal ordering. Precisely at a moment where legal scholars, political scientists and sociologists have come to accept the transnational challenge to the traditional concepts of law and legal regulation, ${ }^{116}$ also the economists' ascription to law, the state and to the correlation between the two as constituting the relevant enforcement framework for economic action needs to be revisited. It is here where we can identify an urgent need and already promising contours of an interdisciplinary inquiry into the nature of 'institutions' of economic and legal governance. Much seems to be at stake: as a utopia of transnational governance continues to linger at the horizon of libertarian imaginations of globally integrated markets, neither discipline appears yet to have an appropriate governance theory at hand. The space of human interaction and of regulation beyond the nation state can be depicted either as the Wild West of unrestrained individual liberty, or as an extremely fragile and contested space of struggles over recognition, politics and community. ${ }^{117}$ In the face of this, has 'law lost its lieu?'118 Is the 'Global Bukowina', which inspired legal sociologists at the respective beginnings and ends of the twentieth century, a realm of law, of social norms or of economic liberties? ${ }^{119}$ What are we to make of these distinctions, after all? To be sure, this process does not continue in a quiet state of contentment and wonder, but rather in surprise, happenstance and terror. ${ }^{120}$ We understand concurring work on 'global governance' to provide an important contribution to a more adequate analysis of the pressing legitimacy and accountability concerns arising from a fragmented regulatory landscape. ${ }^{121}$ In an attempt to complement this research, we posit that an evolutionary perspective on governance offers a further set of insights into the changes in legal and economic governance. It is from this perspective, that we might see emerging 'lessons' from a parallel observation of legal and economic governance. Drawing on the distinction between markets and hierarchies, as developed and expressed in work following Coase ${ }^{122}$ and Williamson ${ }^{123}$ on the one hand and on the analysis of markets as spaces of discovery, learning and adaptation, ${ }^{124}$ on the other, we are in an

\footnotetext{
115 Regarding the slogan as used with reference to legal realism and for the surrounding debate, see Leiter (1996), 261-79.

116 Jessup (1956); Keohane and Nye (2000), 1-41; Harvey (2009).

117 See, for example, Kreide (2009), 18-34; Cotterrell (2008), 1-18.

118 Amstutz (2008), 476. See also Kaldor (2003) (as to the civil society); Brunkhorst (2005); and

Luhmann (1982), 131-8 (describing the fragmentation of world society).

119 See Teubner (1997), 3-28.

120 For recent illustrations, see d. Sousa Santos (2008), 247-270, and Marazzi (2010).

121 Beck (2009); Stone Sweet (2009), 621-45.

122 R. Coase (1937), 386-405.

123 Williamson (1975); Williamson (2000), 595-613; Williamson (2005), 1-18.

124 Hayek (1945), 519-30; Hayek (1968 [2002]), 9-23; Tiebout (1956), 416-24.
} 
increasingly narrow applicatory space for a traditional understanding of legal regulation, as informed by a set of constitutional, normative ideals and embedded in a stable institutional framework. In this situation, however, we are faced with the 'stripping down' of law from a functionalist perspective. This function, in a context of a dramatically changing institutional environment, ${ }^{125}$ re-emerges as a stubborn insistence on the distinction between legal and illegal. In concert with 'economic governance', legal governance finds its place and calling in contra-factually upholding a normative aspiration to continue to make the distinction between legal and illegal - despite the absence of its traditional institutional framework. Law, then, can only purport to illustrate the challenges of having to identify, create and constantly re-adapt the context in which it is possible to make this distinction. This is what is meant with the need for contemporary governance theories to look beyond traditional concepts of political order and democratic governance. ${ }^{126}$

As already illustrated by evolutionary theory's noted 'language deficit', ${ }^{127}$ the same struggle over semantics marks the interdisciplinary confusion over the terms, basis and contours of 'governance'. While it is true, that '[t]oday's problems are determined by the fact that the fundamental structural change of functional differentiation has destroyed the Old European semantics without residue, and that even the most hectic post-modern polysémies can be understood only as a restless search for socially adequate self-descriptions,' catastrophes and the change in social structures lead to a ruining of semantics. ${ }^{128}$ Communication, then, from the perspective of systems theory, constituting the semantics of the particular observing systems such as law, politics, economics and others, is, in the context of fiercely competing 'truth' claims brought forward from different social rationalities, inevitably thrown back onto itself. The legal system must - and will - process the change in its environment by relying on its very own available operations ${ }^{129}$ that now will follow into the depths of societal differentiation to focus on what Mariana Valverde refers to as the small ' $T$ 's in comparison to the large ' $T$ ' in a search for truthfulness. ${ }^{130}$ The same idea applies to other social systems as well, as the recent theorizing over 'institutional diversity' amply illustrates. ${ }^{131}$ Taken together, we are left with contradicting impressions of a world falling apart, of reference systems eroding, on the one hand, and of interdisciplinary enrichment, inspiration and emerging understandings on the other.

This volume accepts this apparent contradiction by bringing together research from different fields and with different perspectives on the problem of institutional evolution. The basis for this volume was an interdisciplinary research project on Law, the State and Evolutionary Theory, jointly conducted by the Collaborative Research Center Transformations of the State at the University of Bremen (Germany) ${ }^{132}$ and the German Law Journal. ${ }^{133}$ In addition to work developed in this context, the present volume

\footnotetext{
125 Compare Willke (2007), Ch. 1 and Ch. 2.

126 Willke, previous note, 7.

127 Dopfer (2005), 3-55, 18.

128 Teubner (2006), 41-64, with reference to Luhmann (2004).

129 Luhmann (1985); Luhmann (1992), 1419-41.

130 Valverde (2003), ch.1.

131 Ostrom (2005); Ostrom (2007), 239-64.

132 www.sfb597.uni-bremen.de

133 www.germanlawjournal.com
} 
contains a number of chapters by some of the most prominent evolutionary theory scholars working today. The collection thus aims at providing a reference point for scholars from different traditions and different fields for an inquiry into the meaning and promises of evolutionary theory for future theorizing about legal and economic governance. The authors contributing to this volume specifically employ evolutionary theory in order to explore the challenges arising from the fundamental transformation of statehood that has been so powerfully captured by Saskia Sassen as an erosion of state sovereignty both from 'below', brought about by processes of privatization and emerging forms of publicprivate governance, and from 'above', through processes of transnationalization of collaborative, regulatory governance. ${ }^{134}$

By contributing to an ongoing exploration of evolutionary approaches to economics, law and their respective intersections, its first and foremost goal is to provide an overview of the variety of evolutionary perspectives, and how these have been contributing to the design of theories of institutional change in response to the contemporary complex realities of legal and economic change. In that sense, the following chapters should be understood as providing a necessary first step for putting forward for discussion a number of methodological elements towards an evolutionary theory that can fruitfully be employed in both law and economics in order to address some of the most pressing questions of contemporary social theory.

\section{OVERVIEW OF THE VOLUME}

Against this background the contributors to this volume reflect on evolutionary approaches to explaining institutional change from different perspectives and, according to the latter, the volume has been constructed around the fundamental parts. Part I (Evolutionary Theory Historical Trajectories), focuses on the use of evolutionary tools in order to explain the historical development of certain specific legal and economic phenomena. In his contribution, Joel Mokyr, provides an astute analysis of the varied impact that the Enlightenment had on the development of economic growth in Europe in the nineteenth century. Central to his argument is the contention that the role played by both attitude (towards technology) and institutions was crucial for the different trajectories in Britain on the one hand and continental Europe on the other. 'The Enlightenment changed the outlook of key persons on their natural environment, and their inventions and discoveries turned what might have become another technological efflorescence into a sea change in economic history. ${ }^{135}$ By insisting on the layered, complex nature of the Enlightenment, Professor Mokyr argues for the need to take into account the long-term development of mind-sets, institutional frameworks and conditions in countries that would otherwise be considered to be affected by the industrial revolution in the same manner. Drawing on scholarship that traced the emergence of a knowledge society in eighteenth-century Europe ${ }^{136}$ and, in particular, the rising recognition and importance

134 See Sassen (2000), 109-116. See also Schepel (2005); and Slaughter (2004), 159-90.

135 Mokyr, in this volume.

136 See, e.g., Burke (2000). 
of 'useful knowledge', Mokyr shows how of all the facets of the Enlightenment the development and consolidation of research-driven knowledge would eventually become the key factor in determining whether or not a country would be able to benefit from and ultimately to drive the revolutionary forces. This process, which Professor Mokyr describes as one of an interaction of prescriptive ('What?') and prepositional ('How?') knowledge, he sees as central to a country's ability to gain competitive advantage (M. Porter). While, in the beginning, somewhat naïve ideas regarding an allegedly unpolitical, scientific debate, that was unfolding on a 'market for ideas' circulated, it quickly became apparent how the quality assessment of offered information was indeed not only central to the development of a sophisticated, knowledge-driven society - and the corresponding political system - but also intimately correlated with its development.

Providing an inspiring contribution to the core challenge of the project informing this collection, i.e. how evolutionary theory can be used as a bridge to make economists and legal scholars speak to each other, Thrainn Eggertsson starts from the premise that economists generally agree that new technologies are the necessary source of long-term economic growth. Based on Solow's contribution to modern (neo-classical) growth theory, and his uses of the letter $A$ to symbolize the stock of technology, Eggertsson stresses how in economic theory, $A$ has a long history of being a nondescript exogenous long-term variable. This disregard is quite peculiar since increasing in $A$ is the basic source of a sustained rise in living standards, but only when new production techniques are supported by complementary social institutions. The application of new production techniques usually requires investment in physical and human capital, which will not be forthcoming in the absence of secure property rights, enforceable contracts, and supportive organizations. Moreover, concludes Eggertsson, appropriate institutions and incentives are required for creating new knowledge since new knowledge and new methods of production are scarce assets that are costly to produce.

With a particular focus on law, Bruce Benson, in his The Law Merchant Story: How Romantic is It?, analyses the use of the term Lex Mercatoria in various historical documents from the Middle Ages in the face of growing criticism, arguing that the descriptions of medieval Law Merchants is either a romantic idea or a pure ex post reconstruction. This contribution then continues by pointing out how the controversy over the Law Merchant actually is definitional, i.e. those who contend that Lex Mercatoria did not exist start from the assumption that the normative system known as 'law' only exists when it is imposed or at least recognized by a sovereign with coercive power. Based on a detailed overview of the medieval Lex Mercatoria, Benson shows how various criticisms of the Law-Merchant literature, for the most part, are much more flawed than the Law Merchant descriptions they attack.

In Part II (Evolutionary Theory in Law and Economics), the contributors investigate, from different doctrinal and normative perspectives, the possible inputs coming from an evolutionary approach in law and legal theory. Taking an example from corporate governance, one of the most dynamic and innovative legal fields in recent years, Fabio Carvalho and Simon Deakin explore the correlations between evolutionary theory and systems theory, in particular the scope for synthesis between systems theory and new institutionalist approaches within economics. While the authors concede that, at first sight, it may seem that the methodological assumptions of economics are too far removed from those of systems theory for any kind of synthesis to be feasible, they argue that economics 
describes itself as a behavioural science which studies the logic of choice under conditions of scarcity. At the same time, systems theory focuses on the communicative processes through which social order is reproduced over time. As economics becomes increasingly concerned with the role institutions play in coordinating the behaviour of economic agents, it encounters a set of issues, which are central to systems theory. According to Carvalho and Deakin, the interdisciplinary field of 'law and economics' provides the terrain on which rival conceptions of the evolutionary process are being advanced and accessible through critical scrutiny. By using examples taken from company law and corporate governance, they suggest that mainstream law and economics approaches treat legal rules as surrogate prices, and contrast this with a conception of law as a cognitive resource upon which agents draw when engaging in production and exchange. By considering the function of the legal system in terms of the reduction and organization of complexity, systems theory provides, according to the two authors, a further dimension to the notion of law as a cognitive resource. In particular, system theory directs attention to the discontinuous and asynchronic quality of legal change where the legal system will maintain a set of 'foundational' concepts which are to a large extent free from immediate evolutionary pressures, and which tend to be manifested in the form of mandatory legal rules which leave little or no room for bargaining between the parties.

In his contribution entitled Constitutional Possibility and Constitutional Evolution, Eric Posner uses evolutionary game theory to explore and tackle recurrent questions about constitutionalism and the United States Constitution. Posner argues that the United States Constitution is a set of self-enforcing conventions that govern how people interact in important ways: the Constitution constrains the government in the same sense that conventions constrain individuals and prevent them from pursuing their immediate self-interest. It is true, continues the author that the Constitution evolves, but it does it at a slow and discontinuous pace, because conventions, by virtue of the fact that they coordinate behaviour, are, in Posner's terminology, 'sticky'. As to the Supreme Court, this body has authority because people believe that it identifies and enforces existing (or hypothetical) conventions. Therefore, justices sitting in the Supreme Court do not always implement their political preferences since otherwise people would stop believing that the Supreme Court enforces conventions, and then the binding force of its decision would decrease to the advantage of other branches.

Richard McAdams, in his chapter, explores what he refers to as a 'third way' of understanding compliance with adjudication. While the two conventional theories are economic - that people fear threatened sanctions - and sociological - that people defer to perceived legitimacy, McAdams invites us to explore an alternative approach which is grounded in social norms theory. Without denying the importance of these mechanisms, McAdams sets out to supplement them with a new causal story for the effect of adjudication. To explain how courts influence behaviour independent of their perceived legitimacy and the sanctions they wield, he argues, one must engage in a peculiar thought experiment imagining a court without these two typical characteristics. The theory of 'expressive adjudication' arises from a previously neglected synergy among three expressive concepts in game theory - 'correlated equilibrium', 'focal point', and 'signal'. McAdams identifies the circumstances in which adjudicative expression can, by itself, influence the behaviour of existing disputants and of future potential disputants. In each case, ambiguity as to the relevant facts or the concepts underlying intentional and spontaneous order 
can cause a conflict that is resolved by clarifying expression. According to McAdams, this expressive power explains otherwise puzzling instances of compliance with tribunals that lack the power of sanctions and unifies theories of third-party norm enforcement with a theory of legal sanctions. Finally, McAdams examines certain normative implications of the expressive theory, including a novel function of adjudicative impartiality, a new justification for the system of public adjudication, and a trade-off between dispute resolution and dispute avoidance. The core of the chapter then consists of a description of an expressive influence that any third party might have over two parties in a dispute. By focusing on the way that the court - here perceived as a third party in correlation to a conflict between two parties - McAdams' chapter provides important insights into the microstructures of institutional development in adjudication, an area that has often only been studied against the backdrop of critical engagements with legal interpretation and judicial activism.

Adopting a perspective similar to that of Richard McAdams but focusing specifically on private regulatory regimes, Amitai Aviram, in his contribution, points out how 'private legal systems', while they tend to be less visible through the traditional institutionalist legal lens, can be studied with regard to their impact on individuals' behaviour and by their interaction with the public legal system. These private legal systems expand to fill voids where the public legal system cannot or does not wish to enforce norms. Together with the public legal system, continues Aviram, two other forces shape the course of the development of private legal system: the 'incumbent's enforcement advantage' (which affects the identity of the private legal system that will enforce the norm) and the 'bias arbitrage' (which impacts the type of norms the private legal systems would choose to enforce). Due to the influence of incumbent's enforcement advantage, private legal systems tend to begin their life enforcing a core norm that has very low enforcement costs. Once this core has developed, Aviram argues, private legal systems may choose expansion norms that can be more expensive to enforce. These expansion norms can benefit from the private legal system's capacity to compel compliance with the new norm by denying a member the benefits of its enforcement of the core norm (and any expansion norms already successfully enforced).

Martina Eckardt's chapter relies on an 'evolutionary economics' perspective to explain legal change. She starts with an overview of typical evolutionary explanations of legal change and identifies the main actors, the key determinants, and the central mechanisms of the different approaches that bring about such change. From an evolutionary economics point of view legal change takes place through the generation and dissemination of legal innovations over time and the main mechanisms are statutory and judge-made legal change. While statutory legal change relies on legislation and thus on collective action, judge-made legal change is brought about by the judiciary through individual lawsuits. Therefore, while to explain legal stability over time the literature stresses the concepts of legal paradigms and of path dependence, with a particular emphasis on legal lockins, in this contribution Eckardt discusses also the main mechanisms that bring about break outs from such legal lock-ins. This enlargement, concludes the author, is done in order to provide a more comprehensive view on legal evolution between stability and change.

In his contribution to this volume, Marc Amstutz, too, adopts an evolutionary perspective on the law-making process but does so by pointing out how systems theory 
neglects to investigate the origin of the law. Law, according to Amstutz, is assumed to have always existed, usually by hiding behind myths produced within the system itself or by the introduction of new categorical differences. However, this assumption cannot be true with regard to law operating in anomy, an example for such a case being transitional justice. Using the Derridian idea of supplément and bringing into relation to Luhmann's idea of law's function consisting in the stabilization of social expectations, it is possible - according to Amstutz - to elaborate a decidedly more complex notion of origin of law. In particular, this Derridian-Luhmannian notion allows, according to Amstutz, the analysis of transitional law on a 'law and society' basis, for instance by revealing the genesis and evolution of the prohibition of crimes against humanity as applied during the Nuremberg trials.

The last two contributions of Part II provide another critical engagement with the promise of evolutionary theory for law and legal theory. Bart Du Laing, in his GeneCulture Co-Evolutionary Theory and the Evolution of Legal Behavior and Institutions, suggests that in explaining institutional change we should draw more attention to its original source, i.e. biological evolutionary theory. The behavioural approach of 'dual inheritance theory', he argues, might prevent legal theory (especially that informed by systems theory) from losing sight of what is happening at lower levels of organization like the behavioural one, including human socio-cultural behaviour. Based on the contemporary evolutionary approach known as 'gene-culture co-evolutionary theory' or 'dual inheritance theory', Du Laing shows how evolutionary analysis in law could benefit from incorporating it into its theoretical framework, in particular by using examples of the field of contract law. After a digression into evolutionary economics and systems theory, the author points out the possible input gene-culture co-evolutionary theory can offer to the study of the transformations of commercial law and its institutions that are of central concern to the research project giving rise to this edited volume.

In his contribution Let's go Normative! Making Evolutionary Theory Useful also for Legal Actors, Mauro Zamboni starts by pointing out the generally sceptical attitude of a large sector of legal scholarship towards the evolutionary approach. In order to make evolutionary theory more useful for and therefore sympathetic to lawyers and legal actors in general, the author suggests shifting evolutionary theory from the position of mere external investigation of the legal phenomenon to being a fundamental contributor to the legal discourse also in its normative parts. The focus in particular is to understand why, though the evolutionary theory approach to law has been around quite a while in the legal scholar's discussion, the legal world has left it at the front step of the legal house. Based on this analysis, Zamboni aims at investigating whether it is possible, after certain adjustments, to invite evolutionary theory into the larger family of legal thinking, in particular as part of the legal theories of law-making. This invitation to join the legal discourse can be done, according to Zamboni, by convincing legal evolutionary scholars to bring the normative components of the evolutionary approach to the surface of their legal discussion in the form of explicit guidelines for future law-making and law-applying.

The first contribution to the third part dealing with the contribution of evolutionary theory to a theory of transnational law and (economic) governance by Wolfgang Kerber focuses on transnational commercial law from an evolutionary economics perspective. After presenting a general introduction into evolutionary economics, Kerber emphasizes the evolutionary concept of competition as innovation-imitation process as well as an 
overview about approaches for explaining institutional change from the perspective of evolutionary economics. In the main section, Kerber aims at demonstrating that both the evolution of public/private governance solutions as well as horizontal and vertical processes of regulatory competition within a multi-level legal system can contribute to the explanation of the evolution of 'transnational commercial law'. In this context, he also emphasizes the importance of conflict/choice of laws rules for this evolution. Kerber concludes that transnational governance solutions are the outcome of complex and interrelated evolutionary competition processes between private and public solutions on one hand and between public solutions of different jurisdictions on the other hand.

Jan Smits, in his chapter, begins by exploring the feasibility of applying evolutionary concepts to the explanation of change in transnational and European private law. His contribution aims at applying insights from evolutionary theory to transnational private law. The goal is to offer a framework for answering in particular to the issue of how it is possible to explain the evolution of law beyond the State (of which transnational commercial law and European private law are prime examples). In this spirit, Smits sets out Darwin's idea of natural selection as the analytical presuppositions underlying the application of evolutionary ideas to the development of private law. He subsequently goes on to apply this idea to legal change (looking at law as an organism) and, in particular, to transnational commercial law and European private law. Smits, finally, points out how, in this respect, the concepts of path dependency, adaptation, and co-existence (diversity) can be extremely helpful.

Following the same path traceable in Smits' contribution, Erich Schanze's chapter explores a variety of 'linkage mechanisms' between law and extra-legal norms, notably national and international standards, which can be found in a number of technical contexts of law ('reference norms'). All reference norms are styled from a legal centrist perspective, i.e. the judicial one starting from the premise that extra-legal norms are relevant only to the extent that a legal norm permits their application. According to Schanze, this perspective is essentially a backward-looking one, taking both legal and extra-legal norms for granted and using legal norms to determine their reciprocal relevance. Since the planning of business transactions requires a different approach, Schanze points out that a shift of perspective is necessary for understanding the relation of law and extra-legal norms. In particular, he proposes to look at the relation between legal and extra-legal norms from a drafting perspective, i.e. a forward-looking perspective, which is complementary to the backward-looking investigation of the linkage mechanisms in their applicative moments and which is largely uncommon to Continental European legal systems.

The last contribution to this part is authored by Gralf-Peter Calliess, Jörg Freiling and Moritz Renner. The authors show how the different perspectives of evolutionary economics and systems theory might complement each other in an interdisciplinary endeavour to explaining institutional change in the governance of cross-border commercial transactions. The aim of Calliess, Freiling and Renner is to outline elements of a consistent conceptual framework, combining elements from both strands of theory, and tie it to the specific field of transnational commerce. Starting from the assumption that international trade operates under circumstances which can appropriately be described as a state of 'lawlessness', the three authors stress how a plethora of private governance mechanisms are available to international commerce. This availability creates a form of economic governance, i.e. provision of 'good order and workable arrangements' for business purposes, 
which is at the same time internationalized and privatized. Nevertheless, they argue, legal regulation is not made obsolete by societal norm-generation, but complements it, competes and interacts with those new modes of governance in many different ways. Calliess, Freiling and Renner conclude their inquiry with an outlook on the possibilities and the problems of integrating evolutionary theory into a social science analysis of institutional change in the transnational arena.

\section{BIBLIOGRAPHY}

Aaken, A. van (2009), 'Effectuating public international law through market mechanisms?', Journal of Institutional and Theoretical Economics, 165.

Aguilera, R., C. Rupp, C.A. Williams, and J. Ganapathi (2004), 'Putting the S back in corporate social responsibility: A multi-level theory of social change in organizations', Academy of Management Review, 32 [http://[papers.ssrn.com/sol3/papers.cfm?abstract_id=567842].

Alchian, A.A. (1950), 'Uncertainty, evolution, and economic theory', Journal of Political Economy, $\mathbf{5 8}, 211-21$.

Alchian, A.A. and H. Demsetz (1972), 'Production information costs, and economic organization', American Economic Review, 62.

Aman, A.C. Jr. (2001), 'The limits of globalization and the future of administrative law: From government to governance', Indiana Journal of Global Legal Studies, 8.

Aman. A., Jr. (2007), 'Law, markets and democracy: A role for law in the neo-liberal state', New York Law School Review, 51.

Arthur, B.W. (1989), 'Competing technologies, increasing returns, and lock-in by historical events', The Economic Journal, 99.

Arthur, B.W. (1994), Increasing Returns and Path Dependence in the Economy, University of Michigan Press.

Baldus, M. (1995), Die Einheit der Rechtsordnung. Bedeutungen einer juristischen Formel in Rechtstheorie, Zivil- und Staatsrechtswissenschaft des 19. und 20. Jahrhunderts. Dunker \& Humblot.

Baumol, W.J. (1986), 'Productivity growth, convergence, and welfare: What the long-run data show', American Economic Review, 76.

Beck, U. (2009) World at Risk [orig. German 'Weltrisikogesellschaft' (Frankfurt: Suhrkamp); Cronin, C. trans], Polity.

Beckert, J. (2007), 'The great transformation of embeddedness. Karl Polanyi and the new economic sociology', Max-Planck-Institut für Gesellschaftsforschung/Max-Planck-Institute for the Study of Societies.

Beckert, M.J. (2009), 'The social order of markets', Theory and Society, 38.

Beckert, J. and W. Streeck (2008), 'Economic Sociology and Political Economy. A Programme Perspective', MPIfG Working Paper 08/4 [http://www.mpifg.de/pu/workpap/wp08-4.pdf]

Berman, P.S. (2005), 'From international law to law and globalization', Columbia Journal of Transnational Law, 43.

Bernstein, L. (1992), 'Opting out of the legal system: Extralegal contractual relations in the diamond industry', Journal of Legal Studies, 21.

Black, J. and D. Rouch (2008), 'The development of global markets as rule-makers: engagement and legitimacy', Law and Financial Markets Review.

Bowler, P.J. (2003), Evolution: The History of an Idea (3rd ed), University of California Press.

Branson, D.M. (1989), 'A corporate paleontologist's look at law and economics in the Seventh Circuit', Chicago-Kent Law Review.

Bratten, W.W. and J.A. McCahery (2001), 'Incomplete contracts theories of the firm and comparative corporate governance', Theoretical Inquiries in Law, 2.

Brown, W.J. (1919), 'Law and evolution', Yale Law Journal, 29. 
Brunkhorst, H. (2005) Solidarity. From Civic Friendship to a Global Legal Community [Flynn, J. trans], MIT Press.

Brunkhorst, H. (ed.) (2009), Demokratie in der Weltgesellschaft, Nomos.

Burke, Peter (2000), A Social History of Knowledge: From Gutenberg to Diderot, London: Blackwell.

Burris, S., M. Kempa and C. Shearing (2008), 'Changes in governance: A cross-disciplinary review of current scholarship', Akron Law Review, 41.

Buxbaum, R. (1996), 'Die Rechtsvergleichung Zwischen nationalem Staat und internationaler Wirtschaft', RabelsZ, 60.

Calliess, G.-P. (2001), 'Lex Mercatoria: A reflexive law guide to an autonomous legal system', German Law Journal, 17 [http://www.germanlawjournal.com/article.php?od=109]

Calliess, G.-P. and M. Renner (2009), 'Between law and social norms: The evolution of global governance', Ratio Juris, 22.

Calliess, G.-P. and P. Zumbansen (2010), Rough Consensus and Running Code: A Theory of Transnational Private Law, Hart Publishing.

Campbell, D. (1997), 'The relational constitution of contract and the limits of "economics": Kenneth Arrow on the social background of markets', in S. Deakin and J. Michie (eds), Contracts, Co-operation, and Competition. Studies in Economics, Management and Law, Oxford University Press.

Campbell, D. (2004), 'The incompleteness of our understanding of the law and economics of relational contract', Wisconsin Law Review.

Catá Backer, L. (2009), 'The OECD Guidelines for Multinational Corporations: Using Soft Law to Operationalize a Transnational System of Corporate Governance'. Law at the End of the Day (blog) [http://Icbackerblog.blogspot.com/2009/03/oecd-guidelines-for-multinational.html].

Charny, D. (1996), 'Illusions of a spontaneous order: "Norms" in contractual relationships', University of Pennsylvania Law Review, 144.

Cheffins, B.R. (2001), 'Does law matter? The separation of ownership and control in the United Kingdom', Journal of Legal Studies, XXX.

Cheffins, B.R. (2004), 'The trajectory of (corporate) law scholarship', Cambridge Law Journal, 63.

Clark, G.L., M.P. Feldman and M.S. Gertler (eds) (2003), Oxford Handbook of Economic Geography, Oxford University Press.

Coase, R. (1937), 'The Nature of the Firm', Economica, 4.

Coase, R.H. (1996), 'Law and economics and A.W. Brian Simpson', Journal of Legal Studies, 25.

Cohen, M.R. (1927), 'Property and Sovereignty', Cornell Law Quarterly, 13.

Cotterrell, R. (2008), 'Transnational communities and the concept of law', Ratio Juris, 21.

Darwin, C. (1859), On the Origin of Species by Means of Natural Selection, or the Preservation of Favoured Races in the Struggle for Life (1st edn).

David, P.A. (1985), 'Clio and the economics of QWERTY', American Economic Review, 75.

David P.A. (2000), 'Path dependence, its critics and the quest for "historical economics", in P. Garrouste and S. Ioannides (eds), Evolution and Path Dependence in Economic Ideas: Past and Present, Edward Elgar.

David, P.A. (2008), 'Path dependence in economic processes: implications for policy analysis in dynamical systems contexts', in K. Dopfer (ed), 'The Evolutionary Foundations of Economics, Cambridge University Press.

Davidson, P. (2009), The Keynes Revolution. The Path to Global Economic Prosperity, Palgrave Macmillan.

Dawson. J.P. (1968), The Oracles of the Law, The University of Michigan Law School.

Demsetz, H. (1967), 'Towards a theory of property rights', American Economic Review, 57.

Dimaggio, P. (ed.) (2001), The Twenty-First Century Firm. Changing Economic Organization in International Perspective, Princeton University Press.

Dopfer, K. (2005), 'Evolutionary economics: a theoretical framework', in K. Dopfer, The Evolutionary Foundation of Economics, Cambridge University Press.

Dosi, G. and F. Malerba (2002), 'Interpreting industrial dynamics twenty years after Nelson and Winter's Evolutionary Theory of Economic Change', Industrial and Corporate Change, 11. 
Drahos, P. and J. Braithwaite (2001), 'The globalisation of regulation', Journal of Political Philosophy, 9.

Drobak, J.N. (ed) (2006), Norms and the Law, Cambridge University Press.

Eggertsson, T. (1990), Economic Behaviour and Institutions, Cambridge University Press.

Eggertsson, T. (1996), 'A note on the economics of institutions' in L.J. Alston, T. Eggertsson and D.C. North (eds), 'Empirical Studies in Institutional Change, Cambridge University Press.

Eidenmüller, H. (1995), Effizienz als Rechtsprinzip. Möglichkeiten und Grenzen der ökonomischen Analyse des Rechts, Siebeck Mohr.

Ellickson, R.C. (1991), Order without Law: How Neighbors Settle Disputes, Harvard University Press.

Ellickson, R.C. (1998), 'Law and economics discovers social norms', Journal of Legal Studies, 27.

Elliott, E.D. (1985), 'The evolutionary tradition in jurisprudence', Columbia Law Review, 85.

Fama, E. (1970), 'Efficient capital markets: A review of theory and empirical work', Journal of Finance, 31.

Fama, E. (1998), 'Market efficiency, long-term returns, and behavioral finance', Journal of Financial Economics, 49.

Fama, E. and M.C. Jensen (1983), 'Agency problems and residual claims', Journal of Law and Economics, 26.

Felix, D. (1998), Einheit der Rechtsordnung. Zur verfassungsrechtlichen Relevanz einer juristischen Argumentationsfigur, Mohr Siebeck.

Fligstein, N. (2001), The Architecture of Markets. An Economic Sociology of Twenty-First-Century Capitalist Societies, Princeton University Press.

Frankenberg, G. (1985), 'Critical comparisons: Re-thinking comparative law', Harvard International Law Journal, 26.

Frazzetto, G. (2004), 'Who's afraid of Darwin?' European Molecular Biology Organization, 5, $662-5$.

Gilson, R.J. and R. Kraakman (1984), 'The mechanisms of market efficiency', Virginia Law Review, 70.

Gilson, R.J. and R. Kraakman (2003), 'The mechanisms of market efficiency twenty years later: The hindsight bias', Journal of Corporate Law, 28.

Glenn, H.P. (2005), 'Doin' the transsystemic; Legal systems and legal traditions', McGill Law Journal, 50.

Gourevitch, P.A. (2003), 'The politics of corporate governance regulation', Yale Law Journal, 112.

Greif, A. (2006), Institutions and the Path to the Modern Economy. Lessons from Medieval Trade, Cambridge University Press.

Guzman, A.T. (2008), How International Law Works. A Rational Choice Theory, Oxford University Press.

Guzman, A.T. (2009), 'Symposium', International Theory, 1.

Hadfield, G.K. (2001), 'Privatizing commercial law', Regulation.

Hadfield, G.K. and E. Talley (2006), 'On public versus private provision of corporate law', Journal of Law, Econ. \& Org., 22.

Haferkamp, H. and N.J. Smelser (1992), 'Introduction' in H. Haferkamp and N.J. Smelser, Social Change and Modernity, University of California Press.

Haken, H. (2005), 'Synergetics: From physics to economics' in K. Dopfer (ed), The Evolutionary Foundation of Economics. Cambridge University Press.

Hale, R.L. (1923), 'Coercion and distribution in a supposedly non-coercive state', Political Science Quarterly, 38.

Hall, P.A. and D. Soskice (eds) (2001), Varieties of Capitalism. The Institutional Foundations of Comparative Advantage, Oxford University Press.

Hardos, P. and D. Rahoc (2008), 'Blundering into wisdom? The Missing elements of Hayek's spontaneous order liberalism. Working Paper [http://ssrn.com/abstract.=1261873].

Harvey, D. (2009), Cosmopolitanism and the Geographies of Freedom, Columbia University Press.

Hayek, F. (1945), 'The use of knowledge in society', American Economic Review, 35.

Hayek, F.A. (1949 [1996]), Individualism and Economic Order, Routledge and Kegan Paul. 
Hayek, F.A. (1968 [2002]), 'Competition as a discovery procedure', M.S. Snow, trans, Quarterly Journal of Austrian Economics, 5, 9-23.

Hayek, F.A. (1960 [2006]), The Constitution of Liberty, Routledge.

Hesselink, M.W. (2008), 'A spontaneous order for Europe? Why Hayek's libertarianism is not the right way forward for European private law', Centre for the Study of European Contract Law, Working Paper Series No 2008/07 [http://ssrn.com/abstract=1270566]

Hollingsworth, J.R. (1997), 'The institutional embeddedness of American capitalism' in C. Crouch and W. Streeck (eds), Political Economy of Modern Capitalism. Mapping Convergence and Diversity, Sage.

Holmes, O.W. (1881), The Common Law, chapters 1 and 2.

Holmes, O.W. (1899), 'Law in science and science in law', Harvard Law Review, 12.

Hovenkamp, H. (2009), 'The Coase theorem and Arthur Cecil Pigou,' Arizona Law Review, 51.

Hull, D.L. (1988), Science as a Process. An Evolutionary Account of the Social and Conceptual Development of Science, University of Chicago Press.

Hull, D.L. (1995), 'Die Rezeption von Darwins Evolutionstheorie bei britischen Wissenschaftsphilosophen des 19. Jahrhunderts', in E.-M. Engels (ed), Die Rezeption von Evolutionstheorien im 19. Jahrhundert, Suhrkamp.

Jensen, M.C. (1970), 'Some anomalous evidence regarding market efficiency', Journal of Financial Economics, 6.

Jessup, P.C. (1956), Transnational Law, Yale University Press.

Johns, F. (2007), 'Performing power: The deal, corporate rule, and the constitution of global legal order', Journal of Law and Society, 34.

Johnson, D.P. (2008), 'The historical background of social Darwinism', in D.P. Johnson, Contemporary Sociological Theory: An Integrated Multi-level Approach.

Kaldor, M. (2003), Global Civil Society: An Answer to War, Polity.

Keller, A.G. (1918), Law in Evolution', Yale Law Journal, 28.

Kennedy, D. (1981), 'Cost-reduction as legitimation', Yale Law Journal, 90.

Kennedy, D. (1982), 'Distributive and paternalist motives in contract and tort law, with special reference to compulsory terms and unequal bargaining power', Maryland Law Review, $\mathbf{4 1 .}$

Keohane, R.O. and J.S. Nye (2000), 'Introduction' in J.S. Nye and J.D. Donahue (eds), Governance in a Globalizing World, Brookings Institution.

Klöhn, L. (2006), Kapitalmarkt, Spekulation und Behavioural Finance. Eine interdisziplinäre und vergleichende Analyse zum Fluch und Segen der Spekulation und ihrer Regulierung durch Markt und Recht, Duncker \& Humblot.

Koven Levit, J. (2007), 'Bottom-up international lawmaking: Reflections on the New Haven School of International Law', Yale Journal of International Law, 32.

Kreide, R. (2009), 'The ambivalence of juridification. On legitimate governance in the international context'. Global Justice: Theory Practice Rhetoric, 2.

Krugman, P. (1992), Geography and Trade, MIT Press.

Krugman, P. (1998), 'What's new about the new economic geography?', Oxford Review of Economics \& Politics, 14.

Ladeur, K.-H. (2000), Negative Freiheitsrechte und gesellschaftliche Selbstorganisation, Mohr Siebeck.

Ladeur, K.-H. (2009), 'The law of the network society' Viellechner L. et al. (eds) German Law Journal. [http://www.germanlawjournal.com/pdf.Vol10No04/pdf_table_of_contents_Vol_10_ No_04.pdf]

Leiter, B. (1996), 'Legal realism', in D. Patterson (ed), A Companion to Philosophy of Law and Legal Theory, Blackwell.

Levi-Faur, D. (2004), 'The global diffusion of regulatory capitalism', The Annals of The American Academy of Political and Social Science, $\mathbf{5 9 8}$.

Lie, J. (1997), 'Sociology of markets', Annual Review of Sociology, 23.

Lindblom, C.E. (1995), 'Market and democracy, obliquely', Political Science and Politics, 28.

Lobel, O. (2004), 'The renew deal: The fall of regulation and the rise of governance in contemporary legal thought' Minnesota Law Review, 89. 
Luhmann, N. (1975), 'Evolution und Geschichte', in: ders., Soziologische Aufklärung 2.

Luhmann, N. (1978), 'Geschichte als Prozeß und die Theorie sozio-kultureller Evolution' in K.-G. Faber and Mayer (eds), Historische Prozesse, Deutscher Taschenbuchverlag.

Luhmann, N. (1982), 'The world society as a social system', International Journal of General Systems, $\mathbf{8}$.

Luhmann, N. (1985), A Sociological Theory of Law, Routledge Kegan \& Paul.

Luhmann, N. (1989), 'Verfassung als evolutionäre Errungenschaft' Rechtshistorisches Journal, 9.

Luhmann, N. (1992), 'Operational closure and structural coupling; the differentiation of the legal system', Cardozo Law Review, 13.

Luhmann, N. (1996), Social Systems [German orig: Bednarz, J. \& Baecker, D. (1984) Transl.], Stanford University Press.

Luhmann, N. (2004), Law as a Social System, K. Ziegert, transl., F. Kastner, D. Schiff, R. Nobles and R. Ziegert (eds), Oxford University Press.

Mahoney, J.T. and J.R. Pandian (1992), 'The resource-based view within the conversation of strategic management', Strategic Management Journal, 13.

Maine, H.S. (1861), Ancient Law, chapter 2.

Marazzi, C. (2010), 'The Violence of Financial Capitalism', Edizioni Casagrande.

Maus, I. (1980), Bürgerliche Rechtstheorie und Faschismus. Zur sozialen Funktion und aktuellen Wirkung der Theorie Carl Schmitts (1976), Wilhelm Fink.

Mokyr, J. (2002), The Gifts of Athena. Historical Origins of the Knowledge Economy, Princeton University Press.

Mokyr, J. (2005a), 'The Knowledge Society: Theoretical and Historical Underpinnings', faculty. wcas.northwestern.edu/-jmokyr/Unitednations.pdf.

Mokyr, J. (2005b), 'Is there a theory of economic history?' in K. Dopfer (ed), The Evolutionary Foundation of Economics, Cambridge University Press.

Möllers, C. (2006), 'European governance; Meaning and value of a concept', Common Market Law Review, 43.

Nee, V. and R. Swedberg (eds) (2005a), The Economic Sociology of Capitalism, Princeton University Press.

Nee, V. and R. Swedberg (2005b), 'Economic sociology and new institutional economics' in C. Ménard and M.M. Shirley (eds), Handbook of New Institutional Economics, Springer.

Nelson, R. (2006), 'Economic development from the perspective of evolutionary economic theory', Working Papers in Technology Governance and Economic Dynamics 2 [http://hum.ttu.ee/ wp.paper $2 /$ pdf]

Nelson. R.J. (1995), 'Recent evolutionary theorizing about economic change', Journal of Economic Literature, 33.

Nelson, R.R. (2007), 'Understanding economic growth as the central task of economic analysis' in F. Malerba and S. Brusoni (eds), Perspectives on innovation, Cambridge University Press, 27-41.

Nelson, R. and S. Winter (1973), 'Toward an evolutionary theory of economic capabilities', American Economic Review, 63.

Nelson, R. and S. Winter (1974), 'Neoclassical vs. evolutionary theories of economic growth: Critique and prospectus', American Economic Review, 84.

Nelson, R. and S. Winter (1982), An Evolutionary Theory of Economic Change, The Belknap Press of Harvard University Press.

Neumann, F.L. (1964), 'The change in the function of law in modern society' in F.L. Neumann (1957), The Democratic and the Authoritarian State.

Nieson, P. and B. Herborth (2007), Anarchie der kommunikativen Freiheit. Jurgen Habermas und die Theorie der internationalen Politik, Suhrkamp.

North, D.C. (1981), Structure and Change in Economic History, Norton.

North, D.C. (1990), Institutions, Institutional Change and Economic Performance, Cambridge University Press.

North, D.C. (1991), 'Institutions', Journal Econ. Persp., 5.

North, D.C. (1994), 'Economic performance through time', American Economic Review, 84.

North, D.C. (2005), Understanding the Process of Economic Change, Princeton University Press.

Ostrom, E. (2005), Understanding Institutional Diversity, Princeton University Press. 
Ostrom, E. (2007), 'Challenges and growth: the development of the interdisciplinary field of institutional analysis', Journal of Institutional Economics, 3.

Posner, E.A. (1998), 'Creating a legal framework for economic development', The World Bank Research Observer, 13.

Posner, E.A. (2000), Law and Social Norms, Harvard University Press.

Priest, G.L. (1977), 'The common law process and the selection of efficient rules', Journal of Legal Studies, 6.

Reimann, M. (2002), 'The progress and failure of comparative law in the second half of the twentieth century', Am. J. Comp. L., 50.

Riles, A. (2005), 'A new agenda for the cultural study of law: Taking on the technicalities', Buffalo Law Review, 53.

Roe, M.J. (1996), 'Chaos and evolution in law and economics', Harvard Law Review, 109.

Roe, M.J. (2002), 'Corporate law's limits', Journal of Legal Studies, 31.

Rosenbaum, E.F. (2000), 'What is a market? On the methodology of a con-tested concept', Review of Social Economy, LVIII.

Rubin, P.H. (1977), 'Why is the common law efficient', Journal of Legal Studies, 6.

Ruttan, V.W. (1997), 'Induced innovation, evolutionary theory and path dependence: Sources of technical change', The Economic Journal, 107.

Sacco, R. (2002), 'Souvernirs d'un vieux comparatiste', ZEuP.

Sassen, S. (2000), 'The State and Economic Globalization: Any Implications for International Law?' Chicago Journal of International Law, 1.

Sassen, S. (2003), 'Globalization or denationalization?', Review of International Political Economy, 10.

Schepel, H. (2005), The Constitution of Private Governance. Product Standards in the Regulation of Integrating Markets, Hart Publishing.

Schulte, M. and R. Stichweh (eds) (2008), Weltrecht, Duncker \& Humblot.

Schumpeter, J. (1934 [1983]), The Theory of Economic Development. With a New Introduction by Elliott, J. E., Transaction Publishers.

Schumpeter, J. (1942 [2008]), Capitalism, Socialism and Democracy with a new introduction by T. McCraw, Harper Perennial Modern Thought.

Scott, C. (2005), A core curriculum for the transnational legal education of JD and LLB students: Surveying the approach of the International, Comparative and Transnational Law Program at Osgoode Hall Law School', Penn State International Law Review, 23.

Scott, R.E. (2004), 'The death of contract law', University of Toronto Law Journal, $\mathbf{5 4}$.

Simpson, A.W.B. (1996a), "Coase v. Rigou” reexamined', Journal of Legal Studies, 25.

Simpson, A.W.B. (1996b), 'An addendum: [A Response to Law and Economics and A.W.B. Simpson by R.H. Coase], Journal of Legal Studies, 25.

Singer, J.W. (1988), 'Legal realism now', California Law Review, 76.

Skidelsky, R. (2009), Keynes. The Return of the Master, Allan Lane.

Slaughter, M. (2004), 'Disaggregated sovereignty: Towards the public accountability of global government networks', Government and Opposition, 39.

Smits, J. (2006), European Private Law: a Plea for a Spontaneous Legal Order', in D. Curtin, J. Smits, A. Klip and J. McCahery (eds), European Integration and Law, Intersentia.

Soskice, D. (1999), 'Divergent production regimes: Coordinated and uncoordinated market economies in the 1980's and 1990's' in H. Kitschelt, P. Lange, G. Marks and J.D. Stephens (eds), Continuity and Change in Contemporary Capitalism, Cambridge University Press.

Sousa Santos B. d. (2008), 'The world social forum and the global left', Politics \& Society, 36.

Stehr, N. (2002), Knowledge and Economic Conduct: The Social Foundations of the Modern Economy, University of Toronto.

Stehr, N. (2005), 'Knowledge Societies' in N. Stehr and V. Meja (eds), Society \& Knowledge. Contemporary Perspectives in the Sociology of Knowledge and Science, Transaction Publishers.

Stehr. N. and Meja, V. (eds) (2005), Society \& Knowledge. Contemporary Perspectives in the Sociology of Knowledge \& Science, Transaction Publishers.

Stone Sweet, A. (2009), 'Constitutionalism, legal pluralism, and international regimes', Indiana Journal of Global Legal Studies, 16. 
Stout, L. (2003), 'The mechanisms of market inefficiency: An introduction to the new finance', Journal of Corporate Law, 28.

Streeck, W. (2001), 'Introduction: Explorations into the origins of nonliberal capitalism in Germany and Japan' in W. Streeck and K. Yamamura (eds), The Origins of Nonliberal Capitalism, Cornell University Press.

Sugden, R. (1989), 'Spontaneous order', Journal of Economic Perspectives, 3.

Sunstein, C. (ed) (2000), Behavioural Law \& Economics, University of Chicago Press.

Swedberg, R. (1998), Max Weber and the Idea of Economic Sociology, Princeton University Press.

Swedberg, R. (2003), 'The case for an economic sociology of law', Theory and Society, 32.

Teubner, G. (1983), 'Substantive and reflexive elements in modern law', Law \& Society Review, 17.

Teubner, G. (1984), 'Autopoiesis in law and society: A rejoinder to Blankenburg', Law and Society Review, 18.

Teubner, G. (1992), 'The two faces of Janus: Rethinking legal pluralism', Cardozo Law Review, 13.

Teubner, G. (1997a), 'The king's many bodies: The self-deconstruction of law's hierarchy', Law \& Society Review, 31.

Teubner, G. (1997b), "Global Bukowina”: Legal pluralism in the world society', in G. Teubner (ed.), Global Law Without a State, Ashgate.

Teubner, G. (1999a) 'Eigensinnige Produktionsregimes: Zur Ko-evolution von Wirtschaft und Recht in den varieties of capitalism', Soziale Systeme, $\mathbf{5}$.

Teubner, G. (1999b), 'After Privatisation? The Many Autonomies of Private Law', in T. Wilhelmsson and S. Hurri From Dissonance to Sense: Welfare State Expectations, Privatisation and Private Law, Ashgate.

Teubner, G. (2002), 'Idiosyncratic production regimes: Co-evolution of economic and legal institutions in the varieties of capitalism', in J. Ziman (ed), The Evolution of Cultural Entities; Proceedings of the British Academy, Oxford University Press.

Teubner, G. (2006), 'Dealing with paradoxes: Derrida, Luhmann, Wiethölter' in O. Perez and G. Teubner (eds), Paradoxes and Inconsistencies in Law, Hart Publishing.

Teubner, G. (2009), 'Self-subversive justice: Contingency or transcendency formula of law?' Modern Law Review, 72.

Thaler, R. (1987), 'Anomalies - The January effect', Journal of Economic Perspectives, 1.

Thaler, R. (1999), 'The end of behavioral finance', Financial Analysts Journal, 55.

Thaler, R. and C. Sunstein (2008), Nudge. Improving Decisions about Health, Wealth and Happiness, Yale University Press.

The World Bank (2009), World Development Report. Reshaping Economic Geography.

Tiebout, C.M. (1956), 'A pure theory of local expenditures', Journal of Political Economy, 64.

Valverde, M. (2003), Law's Dream of a Common Knowledge, Princeton University Press.

Voigt, S. (2002), Neue Institutionenökonomik, Siebeck (UTB).

Watson, A. (1982), 'Legal change: Sources of law and legal culture', University of Pennsylvania Law Review, 131.

White, H.C. (1981), 'Where do markets come from?', American Journal of Sociology, 87.

Whittington, R., M. Mayer and F. Curto (1999), 'Chandlerism in post-war Europe: Strategic and structural change in France, Germany and the UK, 1950-1993', Industrial and Corporate Change, 8.

Wiethölter, R.(1972), 'Artikel Wirtschaftsrecht' in A. Görlitz(ed), Handlexikon zur Rechtswissenschaft, Wissenschaftliche Buchgesellschaft.

Williamson, O.E. (1975), Markets and Hierarchies. Analysis and Antitrust Implications, Free Press.

Williamson, O.E. (1981), 'The modern corporation: Origins, evolution, attributes', Journal of Economic Literature, 19(4).

Williamson, O. (1985), The Economic Institutions of Capitalism, New York, London: Free Press/ Macmillan.

Williamson, O.E. (1996), 'The Institutions and Governance of Economic Development and Reform', Oliver Williamson, the Economics of Governance. 322-343 Oxford University Press.

Williamson, O.E. (2000), 'The new institutional economics: Taking stock, looking ahead', Journal of Economic Literature, 38.

Williamson, O.E. (2005), 'The economics of governance', American Economic Review, 95.

Willke, H. (2007), Smart Governance. Governing the Global Knowledge Society, Campus. 
Zerbe, R.O. Jr. and H. McCurdy (2000), 'The end of market failure', Regulation, 23.

Ziman, J. (2002), The Evolution of Cultural Entities: Proceedings of the British Academy, Oxford University Press.

Zollo, M. and S. Winter (2002), 'Deliberate learning and the evolution of dynamic capabilities', Organization Science, 13.

Zumbansen, P. (2002), 'Piercing the legal veil: Commercial arbitration and transnational law', European Law Journal, 8.

Zumbansen, P. (2006), 'Spaces and places: A systems theory approach to regulatory competition in European company law', European Law Journal, 12.

Zumbansen, P. (2007a), 'The law of society: Governance through contract', Indiana Journal of Global Legal Studies, 14. http://ssrn.com/abstract $=988610$

Zumbansen, P. (2007b), 'Varieties of capitalism and the learning firm. Corporate governance and labor in the context of contemporary developments in European and German company law.' [http://ssrn.com/abstract=993910] European Business Organization Law Review, 8.

Zumbansen, P. (2007c) 'Introduction: Private Ordering in a Globalizing World: Still Searching for the Basis of Contract', Indiana Journal of Global Legal Studies, 14.

Zumbansen, P. (2008a), 'Law after the Welfare State: Formalism, functionalism and the ironic turn of reflexive law', American Journal of Comparative Law, 56.

Zumbansen, P. (2008b), 'New governance in European corporate governance regulation as transnational legal pluralism', European Law Journal, 15. http://ssrn.com.abstract=1128145.

Zumbansen, P. (2009), 'The state as black box and the market as regulator', Journal of Institutional and Theoretical Economics, 165, http://ssrn.com/abstract=1292789

Zumbansen, P. and A. Skordas (2009), 'The Kantian Project of International Law: Engagements with Jürgen Habermas' "The Divided West", German Law Journal, 10. http://www.germanlawjournal.com/index.php?pageID $=2 \& \mathrm{vol}=10 \& \mathrm{no}=1$ 
Peer Zumbansen and Gralf-Peter Calliess - 9781849808989 Downloaded from PubFactory at $04 / 26 / 2023$ 11:36: 03 AM via free access 